Research article

\title{
Effects of common germline genetic variation in cell cycle control genes on breast cancer survival: results from a population-based cohort
}

\author{
Elizabeth M Azzato ${ }^{1,2}$, Kristy E Driver ${ }^{1}$, Fabienne Lesueur ${ }^{1}$, Mitul Shah ${ }^{1}$, David Greenberg ${ }^{3}$, \\ Douglas F Easton 4 , Andrew E Teschendorff5, Carlos Caldas 5 , Neil E Caporaso ${ }^{2}$ and \\ Paul DP Pharoah ${ }^{1}$
}

\author{
1Department of Oncology, University of Cambridge, Strangeways Research Laboratory, Worts Causeway, Cambridge, CB1 8RN, UK \\ ${ }^{2}$ Division of Cancer Epidemiology and Genetics, National Cancer Institute, National Institutes of Health, Executive Plaza South, Rm 7002, 6120 \\ Executive Blvd, Rockville, MD, 20852, USA \\ ${ }^{3}$ Eastern Cancer Registration and Information Centre, Unit C-Magog Court, Shelford Bottom, Cambridge, CB22 3AD, UK \\ ${ }^{4}$ Cancer Research UK Genetic Epidemiology Unit, Department of Public Health and Primary Care, Strangeways Research Laboratory, Worts \\ Causeway, Cambridge, CB1 8RN, UK \\ ${ }^{5}$ Cancer Research UK, Cambridge Research Institute, and Department of Oncology, University of Cambridge, Li Ka Shing Centre, Robinson Way, \\ Cambridge, CB2 ORE, UK \\ Corresponding author: Elizabeth M Azzato, ema32@cam.ac.uk
}

Received: 19 Feb 2008 Revisions requested: 23 Apr 2008 Revisions received: 15 May 2008 Accepted: 28 May 2008 Published: 28 May 2008

Breast Cancer Research 2008, 10:R47 (doi:10.1186/bcr2100)

This article is online at: http://breast-cancer-research.com/content/10/3/R47

(c) 2008 Azzato et al.; licensee BioMed Central Ltd.

This is an open access article distributed under the terms of the Creative Commons Attribution License (http://creativecommons.org/licenses/by/2.0), which permits unrestricted use, distribution, and reproduction in any medium, provided the original work is properly cited.

\begin{abstract}
Introduction Somatic alterations have been shown to correlate with breast cancer prognosis and survival, but less is known about the effects of common inherited genetic variation. Of particular interest are genes involved in cell cycle pathways, which regulate cell division.

Methods We examined associations between common germline genetic variation in 13 genes involved in cell cycle control (CCND1, CCND2, CCND3, CCNE1, CDK2 [p33], CDK4, CDK6, CDKN1A [p21, Cip1], CDKN1B [p27, Kip1], CDKN2A [p16], CDKN2B [p15], CDKN2C [p18], and $C D K N 2 D$ [p19]) and survival among women diagnosed with invasive breast cancer participating in the SEARCH (Studies of Epidemiology and Risk factors in Cancer Heredity) breast cancer study. DNA from up to 4,470 women was genotyped for 85 polymorphisms that tag the known common polymorphisms (minor allele frequency $>0.05$ ) in the genes. The genotypes of each polymorphism were tested for association with survival using Cox regression analysis.
\end{abstract}

Results The rare allele of the tagging single nucleotide polymorphism (SNP) rs2479717 is associated with an increased risk of death (hazard ratio $=1.26$ per rare allele carried, 95\% confidence interval: 1.12 to $1.42 ; P=0.0001$ ), which was not attenuated after adjusting for tumour stage, grade, and treatment. This SNP is part of a large linkage disequilibrium block, which contains CCND3, BYSL, TRFP, USP49, C6ofr49, FRS3, and PGC. We evaluated the association of survival and somatic expression of these genes in breast tumours using expression microarray data from seven published datasets. Elevated expression of the C6orf49 transcript was associated with breast cancer survival, adding biological interest to the finding.

Conclusion It is possible that CCND3 rs2479717, or another variant it tags, is associated with prognosis after a diagnosis of breast cancer. Further study is required to validate this finding.

\section{Introduction}

Excluding non-melanoma skin cancer, breast cancer is the most common cancer in the UK, with 36,939 new cases diag- nosed in 2004 [1]. The prognosis of breast cancer is generally good, with an overall 5-year survival rate of approximately $80 \%$ in England and Wales [2]. Clinical stage at diagnosis,

$\overline{\mathrm{Cl}}=$ confidence interval; ECRIC = Eastern Cancer Registration and Information Centre; ER = estrogen receptor; HR = hazard ratio; LD = linkage disequilibrium; SEARCH = Studies of Epidemiology and Risk factors in Cancer Heredity; SNP = single nucleotide polymorphism; tagSNP= tagging single nucleotide polymorphism; TNM = tumour, node, metastasis. 
including tumour size, lymph node status, and presence of metastases, along with tumour biological factors such as histological grade and type are the most important determinants of prognosis [3].

Cyclins and their regulators, which are involved in cell cycle control, are important as potential oncogenes or tumour suppressor genes in breast cancer [4]. The cell cycle consists of a series of well-controlled events that drive DNA replication and cell division. These events are divided into specific phases: preparation for DNA synthesis $\left(G_{1}\right)$, DNA synthesis $(S)$, a gap phase $\left(G_{2}\right)$, and mitosis $(M)$. Transition between these phases requires tight control; the $G_{1} / S$ phase transition, in particular, includes many cell cycle events that are altered in breast cancer [5]. Somatic alterations in these genes have been shown to correlate with breast cancer prognosis and survival [6-13], but few studies have examined the effects of inherited genetic variation in cell cycle genes. The a870 $\mathrm{g}$ polymorphism of the CCND1 gene (rs603965) has been shown to be associated with breast cancer survival in a large Chinese population-based study [14] and in a small population of patients with metastatic breast cancer [15]. The V109G polymorphism of the p27 gene CDKN1B (rs2066827), examined by polymerase chain reaction analysis of tumour specimens, was associated with shortened disease-free survival in a subset of patients with infiltrating metastasis-free breast cancer [16].

These previous studies, however, were only of selected single nucleotide polymorphisms (SNPs), and the genes involved in the $\mathrm{G}_{1}$ phase of cell cycle control have not been systematically evaluated. The purpose of this study was to assess whether common germline genetic variation in these genes is associated with breast cancer survival by using a comprehensive SNP tagging approach to efficiently capture the common variation. Thirteen genes involved in the $\mathrm{G}_{1}$ phase of the cell cycle have been investigated in this study, including those that encode for the cyclin family that regulate cyclin-dependent kinases (CCND1, CCND2, CCND3, and CCNE1); cyclindependent kinases, which are necessary for the $\mathrm{G}_{1} / \mathrm{S}$ transition (CDK2 [p33], CDK4, and CDK6); and cyclin-dependent kinase inhibitors (CDKN1A [p21, Cip1], CDKN1B [p27, Kip1], CDKN2A [p16], CDKN2B [p15], CDKN2C [p18], and CDKN2D [p19]).

\section{Materials and methods Study population}

Cases were selected from the Studies of Epidemiology and Risk factors in Cancer Heredity (SEARCH) breast cancer study, an ongoing population study of women diagnosed with breast cancer in the region of England included in the Eastern Cancer Registration and Information Centre (ECRIC) (formerly the East Anglian Cancer Registry). Eligible participants include women diagnosed with invasive breast cancer who were either under 70 years of age since the beginning of the study on 1 July 1996 (incident cases) or age 55 or younger since 1 January 1991 and who were alive at the start of the study (prevalent cases). Due to boundary changes, some prevalent cases diagnosed before 1995 were identified by the North Thames Cancer Registry.

Of those eligible, 67\% returned a comprehensive epidemiological questionnaire and $64 \%$ returned a blood sample for genotyping. All participants in the study provided informed consent, and the study was approved by the Eastern Multicentre Research Ethics Committee. DNA is available from 4,470 cases for genotyping; $27 \%$ of these participants are prevalent cases.

The samples have been split into two sets in order to save DNA and reduce genotyping costs. Cases with high genomic yield were randomly selected from the first 3,500 recruited to comprise set 1 ( $n=2,270)$, with set 2 comprising the remainder of these plus the next 970 incident cases recruited $(n=$ 2,200 ). DNA yield was not associated with genotype for those cases included in set 1 or set 2 . SNPs showing a positive association with survival after a diagnosis of breast cancer $(P$ trend $<0.05)$ were genotyped in set 2 . Data from both sets were then combined ( $n=4,470$ ) to jointly analyze the SNPs with positive associations. This joint analysis approach results in increased power to detect genetic association despite more stringent significance levels with Bonferroni correction [17].

As the prevalent cases were the first recruited, the proportion of prevalent cases was somewhat higher in set 1 than set 2 (33\% versus $20 \%$ ). In total, 1,370 prevalent cases were included in both sets; median time from diagnosis to blood draw was 3.4 years (range: 0.8 to 9.34 years). Median age at diagnosis was similar in the two sets (50 and 53 years old, respectively). Median time from diagnosis to blood draw was slightly longer for set 2 (18 months) than for set 1 ( 9 months), but the number of deaths in each set was similar (359 in set 1 and 278 in set 2). There was no significant difference in the morphology, histopathological grade, or TNM (tumour, node, metastasis) stage [18] of the cases by set or by prevalent/incident status.

\section{Participant follow-up}

The ECRIC and the North Thames Cancer Registry have active follow-up at years 3 and 5 after diagnosis and then at 5year intervals. Follow-up information and all-cause mortality are obtained by searching hospital information systems for recent visits. If a patient has not had a recent visit, the patient's general practitioner is contacted to obtain the vital status. Death certificate flagging through the Office of National Statistics also provides the registries with notification of deaths. The lag times with this process are a few weeks for cancer deaths and 2 months to a year for non-cancer deaths. Cause-specific mortality was obtained from part I of the death certificate. 


\section{Gene/single nucleotide polymorphism selection}

Thirteen genes involved in the $G_{1}$ phase of cell cycle regulation were selected as candidate genes for breast cancer survival. A comprehensive SNP tagging approach was used in which tagging SNPs (tagSNPs) were chosen to capture all known common genetic variation in each gene with an estimated correlation coefficient $\left(r^{2}\right)$ of greater than 0.8 . In some cases, SNPs that were poorly correlated with other single SNPs could be efficiently tagged with a haplotype defined by multiple SNPs. Correlation between these SNPs and the haplotype of tagSNPs $\left(r_{s}^{2}\right)$ was aimed to be greater than 0.8. TagSNPs were identified with the program Tagger [19]. Data from the International HapMap Project [20] and resequencing data from the National Institute of Environmental Health Sciences (NIEHS) Environmental Genome Project [21] were used to select tagSNPs. In total, 85 tagSNPs were chosen.

\section{Genotyping}

Genotyping was carried out using the TaqMan ${ }^{\circledR}$ platform (Applied Biosystems, Foster City, CA, USA) according to the manufacturer's instructions. Primers and FAM- and VIClabeled probes were supplied directly by Applied Biosystems as Assays-by-Design ${ }^{\mathrm{TM}}$. All assays were carried out in 384-well plates. Each plate included negative controls (with no DNA) and positive controls duplicated on a separate quality control plate. Plates were read on the ABI Prism 7900 using Sequence Detection Software (Applied Biosystems). Failed genotypes were not repeated. Assays in which the genotypes of duplicate samples did not show greater than $95 \%$ concordance were discarded and replaced with alternative assays with the same tagging properties. Call rates for each assay were over $95 \%$.

\section{Statistical methods}

Cox regression analysis was performed to determine the effect of each tagSNP on survival. The proportional hazards assumption was evaluated by visual inspection of log-log plots as well as tested analytically using Schoenfeld residuals. TagSNPs significantly associated with survival were re-evaluated in a model adjusted for known breast cancer prognostic factors, which included age at diagnosis $(<40,40$ to 49,50 to 59 , or $>60$ years), clinical stage (TNM stage $1,2,3$, or 4 ), histopathological grade (well differentiated, moderately differentiated, or poorly differentiated), estrogen receptor (ER) status, and treatment.

Time at risk began on the date of blood sample receipt and ended on the date of death from any cause or, if death did not occur, on 30 November 2006. This allows for the difference in ascertainment of incident and prevalent cases and provides an unbiased estimate of the relative hazard provided that the proportional hazards assumption is correct. Follow-up was censored at 10 years after diagnosis as follow-up became less reliable for each individual after 10 years. A hazard ratio (HR) was estimated for heterozygous and rare homozygous geno- types relative to the common genotype. Primary tests used were a likelihood ratio test (2 degrees of freedom) for heterogeneity of risk among the three genotypes (common homozygote, heterozygote, and rare homozygote) and a trend test (1 degree of freedom) based on the number of rare alleles carried. All analyses were performed with Intercooled Stata, version 8.2 (StataCorp LP, College Station, TX, USA).

\section{Results}

\section{Survival analysis}

The characteristics of the SEARCH breast cancer study participants for whom genotyping and vital status data were available are described in Table 1. More than 99\% of the cases were Caucasian. There were 3,263 (73\%) cases enrolled as incident cases and 1,207 (27\%) as prevalent cases. No significant difference in survival hazard was found between the two groups $(P=0.19)$. During the 25,049 person-years at risk, there were 637 deaths before 10 years of follow-up. Five hundred forty-two of these deaths were coded as breast cancerspecific.

\section{Set 1 analysis}

The results of the univariate Cox regression analyses for single marker tagSNPs are shown in Supplementary Table 1 and for multimarker tagSNPs in Supplementary Table 2 (Additional File 1). None of the tagSNPs in CCND1, CCND2, CCNE1, CDK2, CDK4, CDK1A, CDKN1B, CDKN2A, CDKN2B, $C D K N 2 C$, or $C D K N 2 D$ were significantly associated with allcause survival. The trend tests for CCND3 rs2479717, CCND3 rs9529, and CDK6 rs2079147 were significant at the 0.05 level $(P=0.001,0.006$, and 0.02 , respectively). CCND3 rs2479717 and CCND3 rs9529 are highly correlated with each other $\left(r^{2}=0.92\right)$. In a forced Cox regression model including both CCND3 rs2479717 and CCND3 rs9529, only CCND3 rs2479717 remained significant $(P=$ 0.029). Therefore, only CCND3 rs2479717 and CDK6 rs2079147 were genotyped in the second set.

\section{Joint analysis}

CCND3 rs2479717 remained significant in the joint analysis (HR per rare allele carried $=1.26,95 \%$ confidence interval [Cl]: 1.12 to $1.42 ; P=0.0001$ ) (Figure 1). Data on tumour grade, TNM stage, and age at diagnosis were available for $80 \%, 97 \%$, and $100 \%$ of the cases, respectively. Only stage and grade remained significantly associated with survival in the multivariate model. Radiotherapy, chemotherapy, and adjuvant hormone therapy treatment data were available for 4,303 $(96.3 \%)$ cases. Of these, 1,412 (32.8\%) underwent chemotherapy, 3,006 (69.9\%) were treated with adjuvant hormone therapy, and 3,099 (72.0\%) received radiotherapy. Surgical treatment information was available for 4,194 (93.8\%) cases; of these, $3,840(91.6 \%)$ underwent surgery. The risk associated with CCND3 rs2479717 was not significantly attenuated after adjusting for tumour stage, grade, radiotherapy, chemotherapy, adjuvant hormone therapy, and surgery (HR 
Table 1

\section{SEARCH participant survival characteristics}

\begin{tabular}{|c|c|c|c|c|}
\hline \multirow[b]{2}{*}{ Total time at risk, years } & \multicolumn{2}{|c|}{$\begin{array}{c}\text { Set } 1 \\
n=2,270\end{array}$} & \multicolumn{2}{|c|}{$\begin{array}{c}\text { Sets } 1 \text { and } 2 \\
n=4,470\end{array}$} \\
\hline & $1,3851.47$ & & $2,5049.24$ & \\
\hline Median follow-up, years ${ }^{a}$ & 7.75 & $(0.56-10)^{b}$ & 7.45 & $(0.48-10)^{b}$ \\
\hline Median time at risk, years & 6.47 & $(0.10-9.64)^{b}$ & 5.70 & $(0.03-9.77)^{b}$ \\
\hline Median time from diagnosis to study entry, years & 0.73 & $(0.00-8.64)^{b}$ & 1.16 & $(0.00-9.34)^{b}$ \\
\hline Number of deaths & 359 & & 637 & \\
\hline Annual mortality rate & 0.026 & & 0.025 & \\
\hline 5-year survival rate & 0.88 & $(0.86-0.89)^{c}$ & 0.88 & $(0.87-0.89)^{c}$ \\
\hline Median age at diagnosis, years & 50.2 & $(25-69)^{b}$ & 51.0 & $(23-69)^{b}$ \\
\hline \multicolumn{5}{|l|}{ Age at diagnosis, years } \\
\hline$<40$ & 212 & $9.30 \%$ & 394 & $8.81 \%$ \\
\hline $40-49$ & 753 & $33.20 \%$ & 1,331 & $29.78 \%$ \\
\hline $50-59$ & 997 & $43.90 \%$ & 1,802 & $40.31 \%$ \\
\hline $60+$ & 308 & $13.60 \%$ & 943 & $21.10 \%$ \\
\hline \multicolumn{5}{|l|}{ Histopathological grade } \\
\hline Well differentiated & 434 & $19.11 \%$ & 871 & $19.49 \%$ \\
\hline Moderately differentiated & 787 & $34.67 \%$ & 1,687 & $37.74 \%$ \\
\hline Poorly differentiated & 504 & $22.20 \%$ & 1,019 & $22.80 \%$ \\
\hline Unknown & 545 & $24.00 \%$ & 893 & $19.98 \%$ \\
\hline \multicolumn{5}{|l|}{ Morphological type } \\
\hline Ductal & 1,674 & $73.74 \%$ & 3,316 & $74.18 \%$ \\
\hline Lobular & 351 & $15.46 \%$ & 659 & $14.74 \%$ \\
\hline Other & 222 & $9.78 \%$ & 455 & $10.17 \%$ \\
\hline Unknown & 23 & $1.01 \%$ & 40 & $0.89 \%$ \\
\hline \multicolumn{5}{|l|}{ Clinical stage } \\
\hline 1 & 1,112 & $48.99 \%$ & 2,190 & $48.99 \%$ \\
\hline 2 & 986 & $43.33 \%$ & 1,981 & $44.32 \%$ \\
\hline 3 or 4 & 172 & $7.58 \%$ & 194 & $4.34 \%$ \\
\hline Missing & 0 & $0 \%$ & 105 & $2.35 \%$ \\
\hline
\end{tabular}

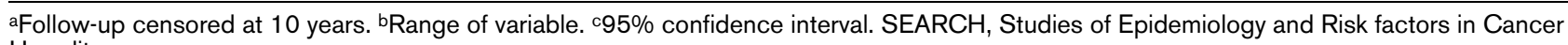
Heredity.

per rare allele carried $=1.23,95 \% \mathrm{Cl}: 1.07$ to $1.41 ; P=$ $0.003)$. We repeated the analysis in those recruited within 3 years of diagnosis (3,558 individuals), and there were no differences in the results for both the univariate analysis (HR per rare allele carried $=1.28,95 \% \mathrm{Cl}: 1.13$ to $1.46 ; P=0.0002)$ and the multivariate model (HR per rare allele carried $=1.23$, 95\% Cl: 1.07 to $1.42 ; P=0.004)$.

ER status was available for $2,624(58.7 \%)$ cases. Of these, $1,975(75.3 \%)$ individuals had an ER-positive tumour. No dif- ferences across stage, grade, or ER status are noted across the rs2479717 genotype (Table 2). If ER status is added to the multivariate model, the power of the model is somewhat decreased due to a reduction in sample size, resulting in a slight attenuation of the HR and loss of significance for CCND3 rs2479717 ( $\mathrm{HR}=1.13,95 \% \mathrm{Cl}: 0.94$ to $1.35 ; P=$ 0.19). The HR for CCND3 rs2479717 was almost the same for those individuals with an ER-positive tumour (HR per rare allele carried $=1.13 ; 95 \% \mathrm{Cl}: 0.91$ to 1.41 ) and those with an ER-negative tumour (HR per rare allele carried $=1.12,95 \%$ 
Figure 1

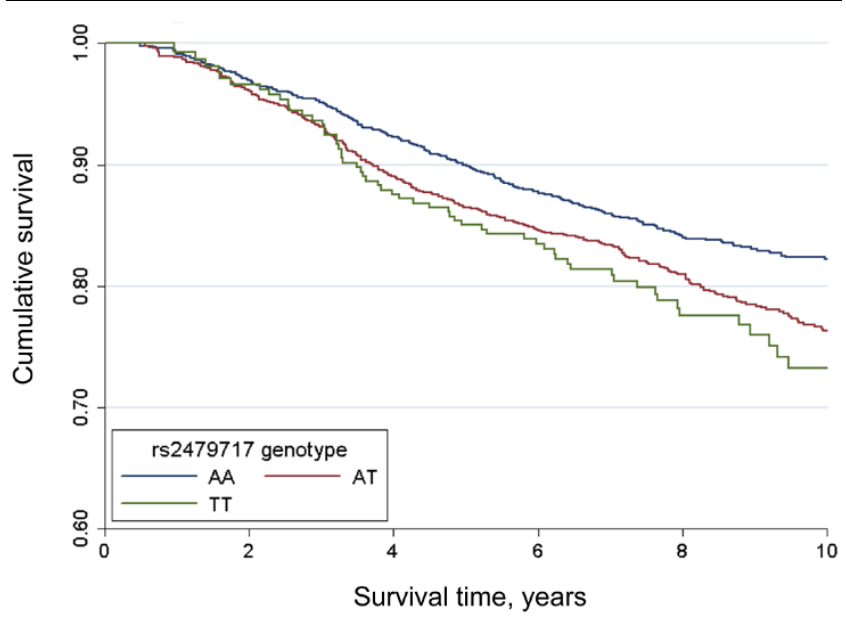

Kaplan-Meier survival function by CCND3 rs2479717 genotype. Kaplan-Meier survival probabilities for women diagnosed with invasive breast cancer in the SEARCH (Studies of Epidemiology and Risk factors in Cancer Heredity) breast cancer study by rs2479717 genotype are shown.

$\mathrm{Cl}: 0.89$ to 1.43$)$; the test for interaction was not significant $(P$ $=0.97$ ).

Results were consistent for breast cancer-specific mortality (Supplementary Tables 3 and 4 found in Additional File 2). Only CCND3 rs2479717 remained significant in the joint analysis (HR per rare allele carried $=1.26,95 \% \mathrm{Cl}: 1.11$ to $1.44 ; P=0.0004)$. This HR was not attenuated by stage, grade, and treatment (HR per rare allele carried $=1.21,95 \%$ $\mathrm{Cl}: 1.04$ to $1.40 ; P=0.01$ ).

\section{Somatic expression analysis}

CCND3 rs2479717 is an a $>t$ intronic alteration approximately 50 bases downstream from exon 3 . It lies in a large linkage disequilibrium (LD) block on chromosome 6, which contains seven genes: CCND3, BYSL, TRFP, USP49, C6ofr49, FRS3, and PGC (Figure 2). To further evaluate the effect of these genes on breast cancer survival, microarray gene expression data for seven breast cancer cohorts were taken from existing literature and public databases (Gene Expression Omnibus and ArrayExpress) [22-28]. The publicly available data comprise raw expression data that have been 'normalized'. This usually involves background correction, quantile normalization, and log transformation. The retrieved datasets were further normalized, if necessary, by transforming them onto a common log2 scale and shifting the median of each array to zero [29].

Study characteristics are included in Table 3. In total, the studies included tumour samples from 1,241 individuals. All of the studies contained clinical outcomes; five of the studies had information on all-cause mortality, and two of the studies had disease recurrence as an outcome. Most of the studies had a mix of untreated and treated individuals, with treatment including both chemotherapy and/or hormonal therapy. Median age at diagnosis ranged from less than 53 years to 65 years. The majority of tumours were ER-positive and medium grade (Supplementary Table 5 found in Additional File 3). Combined, the datasets provided 9,048 years at risk (median of 7.4 years at risk) and a total of 384 events.

To test whether a gene's expression is associated with clinical outcome, we used Cox proportional hazards regression models. In this context, the HR refers to the proportional increase in hazard risk per unit increase on a log2 scale of expression level of the transcript. To attempt to control for study heterogeneity, expression data for each gene were analyzed two ways: a Cox survival model stratified by study (fixed effects) and a random-effects meta-analysis. Elevated expression levels of the BYSL transcript were significantly associated with breast cancer survival in a random-effects model $(H R=1.84$, 95\% Cl: 1.10 to 3.08; $P=0.02$ ) (Figure 3a), but the association did not reach significance in a fixed-effects model $(\mathrm{HR}=$ 1.17, 95\% Cl: 0.99 to $1.38 ; P=0.08$ ). Elevated expression levels of the C6orf49 transcript were significantly associated with breast cancer survival in a fixed-effects model $(H R=1.60$, 95\% Cl: 1.18 to $2.16 ; P=0.002)$ and in a random-effects model (HR=1.84, 95\% Cl: 1.11 to $3.05 ; P=0.02)$ (Figure 3b). Expression levels of CCND3, TRFP, USP49, FRS3, or $P G C$ transcripts were not significantly associated with breast cancer survival (Supplementary Table 6 found in Additional File 3).

\section{Discussion}

We have evaluated the association of 85 tagSNPs in 13 cell cycle control genes with survival after a diagnosis of breast cancer. Previous work has shown that expression of these genes is associated with breast cancer prognosis; however, to our knowledge, this is the first study to systematically assess germline variation in genes involved in controlling the cell cycle and breast cancer survival.

This study used a two-stage design, with an initial set of 85 tagSNPs genotyped in 2,270 individuals. The top two SNPs, with a $P$ value of less than 0.05 , were genotyped in the second set of patients $(n=2,200)$. Because a combined analysis with adjustment for multiple testing has been shown to increase power over a replication study, a joint analysis of both sets of data was performed. One SNP, CCND3 rs2479717, showed a significant association with survival after a diagnosis of breast cancer (unadjusted $P$ value $=0.0001$ ). This finding remains significant after a conservative Bonferroni correction for multiple testing ( $P$ value $=0.0085$ ), and the HR is not significantly attenuated after adjusting for stage, grade, and treatment. There was no evidence of association with survival for polymorphisms in CCND1, CCND2, CCNE1, CDK2, CDK4, CDK6, CDKN1A, CDKN1B, CDKN2A, CDKN2B, CDKN2C, and $C D K N 2 D$. 
Table 2

CCND3 rs2479717 genotype frequency across stage, grade, and estrogen receptor status

\begin{tabular}{|c|c|c|c|c|}
\hline & \multicolumn{4}{|c|}{ CCND3 rs2479717 genotype } \\
\hline & AA & AT & $\mathrm{TT}$ & Missing \\
\hline \multicolumn{5}{|l|}{ Stage } \\
\hline 1 & $1,193(54.5 \%)$ & $808(36.9 \%)$ & $142(6.5 \%)$ & $48(2.2 \%)$ \\
\hline 2 & $1,031(52.0 \%)$ & $753(38.0 \%)$ & $145(7.3 \%)$ & $54(2.7 \%)$ \\
\hline 3 or 4 & $90(46.4 \%)$ & $82(42.3 \%)$ & $17(8.8 \%)$ & $5(2.6 \%)$ \\
\hline Missing & $60(58.8 \%)$ & 31 (30.4\%) & 9 (8.8\%) & $2(2.0 \%)$ \\
\hline \multicolumn{5}{|l|}{ Grade } \\
\hline 1 & $484(55.4 \%)$ & $314(35.9 \%)$ & $60(6.9 \%)$ & $16(1.8 \%)$ \\
\hline 2 & $889(52.7 \%)$ & $658(39.0 \%)$ & $104(6.2 \%)$ & $36(2.1 \%)$ \\
\hline 3 & $533(52.3 \%)$ & $375(36.8 \%)$ & $86(8.4 \%)$ & $26(2.5 \%)$ \\
\hline Missing & $468(52.5 \%)$ & $327(36.7 \%)$ & $63(7.1 \%)$ & $34(3.8 \%)$ \\
\hline \multicolumn{5}{|c|}{ Estrogen receptor status } \\
\hline Positive & $1,089(55.1 \%)$ & $717(36.3 \%)$ & $130(6.6 \%)$ & $39(2.0 \%)$ \\
\hline Negative & $320(49.3 \%)$ & $262(40.4 \%)$ & $53(8.2 \%)$ & $14(2.2 \%)$ \\
\hline Missing & $965(52.3 \%)$ & $695(37.6 \%)$ & $130(7.0 \%)$ & $56(3.0 \%)$ \\
\hline
\end{tabular}

These findings were based on the analysis of all-cause mortality. This may result in a reduction of statistical power as some deaths will be unrelated to breast cancer. Breast cancer-specific mortality was available from death certificates, and the results were consistent for the breast cancer-specific analysis, with an identical HR for CCND3 rs2479717. It is worth noting that cause of death as coded on a death certificate is also prone to misclassification and subsequent loss of statistical power.

Our analyses incorporated prevalent cases. It may be thought that inclusion of prevalent cases may result in a bias of the HR. However, provided that the Cox proportional hazards assumption holds true, the HR estimate is unbiased. For example, there is no significant difference between the HRs for CCND3 rs2479717, TNM stage, or histopathological grade when comparing subjects recruited within 6 months of diagnosis with those recruited more than 6 months after diagnosis $(P=$ $0.69,0.90$, and 0.42 , respectively). Furthermore, our repeated analyses, including only those individuals recruited within 3 years of their diagnosis, were identical to our full analysis.

CCND3 encodes for cyclin D3, a protein involved in the regulation of the $G_{1} / S$ phase transition. The SNP associated with survival, CCND3 rs2479717, is in an intron and unlikely to have a functional effect. However, a functional effect would not be expected as it was chosen as a tagSNP, not as a functional SNP. Furthermore, a functional variant tagged by this SNP may not even alter the function of CCND3; the SNP lies in a large LD block with several genes that are reasonable candidates for breast cancer survival. PGC encodes for pepsinogen $\mathrm{C}$, a proteolytic enzyme involved in digestion, which is expressed in breast tumours [30]. Higher pepsinogen $\mathrm{C}$ expression is associated with well-differentiated and moderately differentiated breast tumours [31] and has been associated with longer overall survival in these patients [32,33]. $B Y S L$ encodes for bystin, a crucial component protein of an adhesion molecule complex that is important for the attachment of the embryo to the uterus [34]. This protein is present in human prostatic carcinoma cells in areas of perineural invasion in an increasing gradient, suggesting a role in perineural adhesion [35]. C6orf49 encodes for overexpressed breast tumour protein, a member of the LIM domain (cysteine-rich double zinc fingers) protein family that is overexpressed in tumours and has a possible role in cancer differentiation [36,37]. FRS3 encodes for fibroblast growth factor receptor substrate 3 , a negative regulator in epidermal growth factor receptor tyrosine kinase signaling pathways [38,39]. USP49 encodes for ubiquitin-specific protease 49 , which is involved in the modification of cellular proteins. Ubiquitin-specific protease 49 is expressed in samples derived from tumour biopsies [40]. TRFP encodes for TATA-binding protein-related 
Figure 2

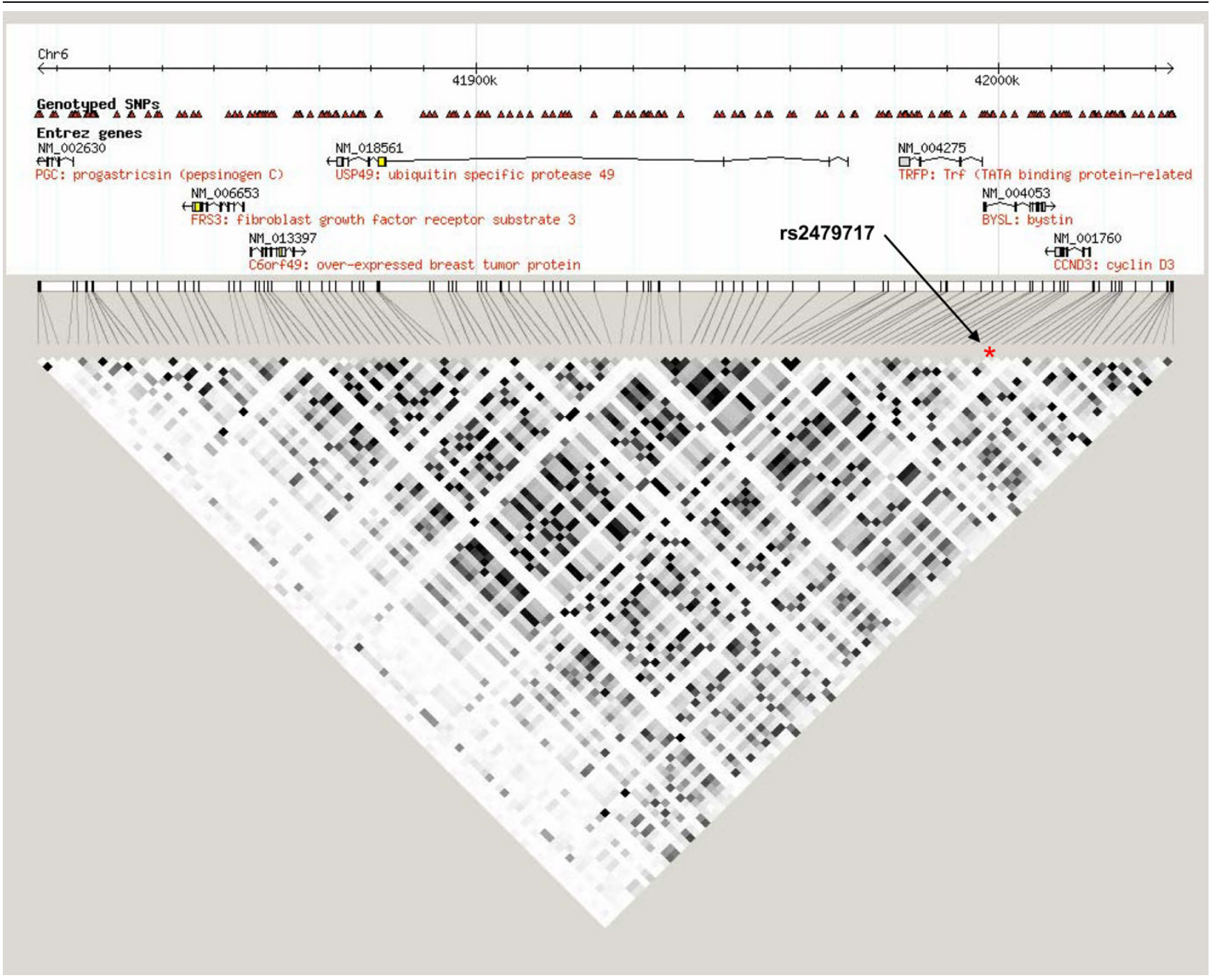

Linkage disequilibrium block surrounding CCND3 rs2479717. This 219-kilo-base pair section on chromosome 6 contains the genes CCND3, BYSL, TRFP, USP49, C6ofr49, FRS3, and PGC, mapped relative to common single nucleotide polymorphisms on HapMap CEU. Squares indicate pairwise $r^{2}$ on a grayscale (black $=1$, white $=0$ ). The position of rs 2479717 is denoted by a red asterisk.

protein, which is associated with an RNA polymerase II-SRB complex; this complex may regulate class II genes [41].

To further evaluate this LD block, we examined breast tumour expression of these seven genes using expression microarray data from seven published datasets. Significant associations between increased tumour expression levels of BYSL and C6orf49 transcripts and breast cancer survival emerged. Differences between the microarray datasets, varying outcome information, and incomplete control of confounding by prognostic factors may limit interpretation of these findings; however, we attempted to control for patient and tumour heterogeneity between these studies by performing two analyses: a random-effects and a fixed-effects meta-analysis. Although the results for $B Y S L$ are unclear, both analyses showed consistent associations of elevated tumour expression of the
C6orf49 transcript with survival after a diagnosis of breast cancer.

\section{Conclusion}

Our study has found evidence that tagSNP CCND3 rs2479717, which is found in a genomic region that includes CCND3 and six other genes, is associated with survival after a diagnosis of breast cancer. Although our study began as an evaluation of cell cycle control genes, our significant finding may actually relate to a gene in LD with CCND3 rs2479717 that is not related to cell cycle control. This is supported by our findings that elevated tumour expression of the C6orf49 transcript, one of the genes in LD with rs2479717, is associated with breast cancer survival. If our findings can be confirmed in other studies, further evaluation of this locus to identify the causal variant would be warranted. 
Figure 3

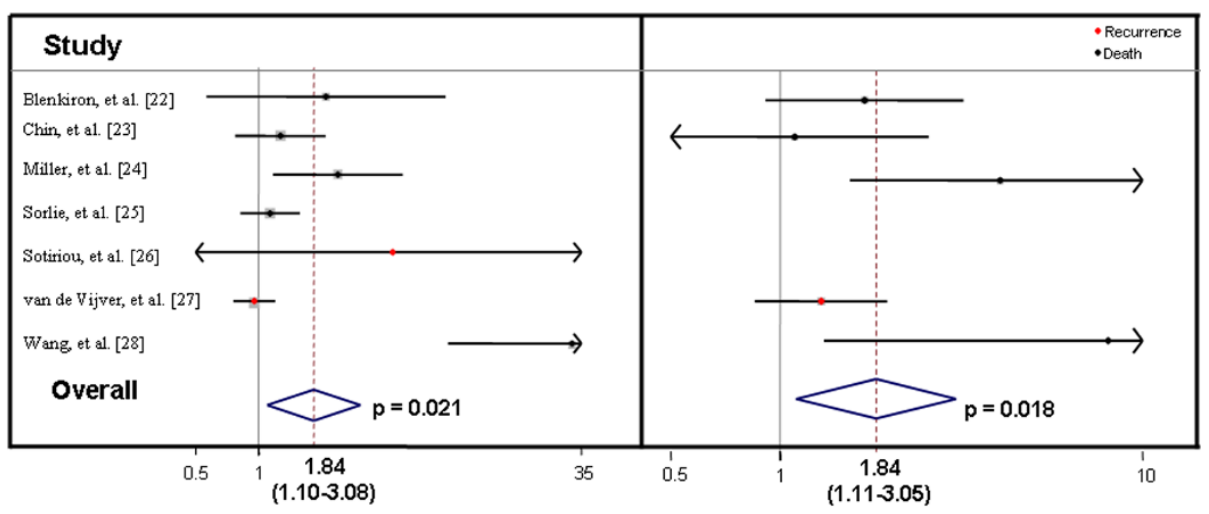

$\begin{array}{ll}\text { (a) BYSL } & \text { (b) C6orf49 }\end{array}$

Association of BYSL (a) and C6orf49 (b) breast tumour expression with breast cancer outcome. Forest plots are shown for random-effects metaanalyses of breast tumour expression of BYSL and C6orf49 evaluated by microarray and association with breast cancer recurrence or death. Studyspecific hazard ratios with confidence intervals and an overall estimate of effect are shown. Grey boxes indicate the weight of study in randomeffects meta-analysis.

Table 3

\section{Microarray study characteristics}

\begin{tabular}{|c|c|c|c|c|c|c|c|c|}
\hline Study & Institution & Outcome & $\begin{array}{l}\text { Microarray } \\
\text { platform }\end{array}$ & $\begin{array}{l}\text { Evaluated } \\
\text { genes }\end{array}$ & $\begin{array}{l}\text { Number of } \\
\text { samples }^{\mathrm{a}}\end{array}$ & $\begin{array}{l}\text { Total time at } \\
\text { risk, years }\end{array}$ & $\begin{array}{l}\text { Median time } \\
\text { at risk, years }\end{array}$ & $\begin{array}{c}\text { Number } \\
\text { deaths/ } \\
\text { recurrences }\end{array}$ \\
\hline $\begin{array}{l}\text { Blenkiron, et } \\
\text { al. [22] }\end{array}$ & $\begin{array}{l}\text { Nottingham } \\
\text { City Hospital } \\
\text { (Nottingham, } \\
\text { UK) }\end{array}$ & $\begin{array}{l}\text { All-cause } \\
\text { mortality }\end{array}$ & $\begin{array}{l}\text { Illumina (San } \\
\text { Diego, CA, } \\
\text { USA) }\end{array}$ & $\begin{array}{l}\text { PGC, FRS3, } \\
\text { C6orf49, } \\
\text { TRFP, BYSL, } \\
\text { USP49, } \\
\text { CCND3 }\end{array}$ & 128 & $1,198.0$ & 11.1 & 45 \\
\hline $\begin{array}{l}\text { Chin, et al. } \\
\text { [23] }\end{array}$ & $\begin{array}{l}\text { University of } \\
\text { California at } \\
\text { San } \\
\text { Francisco }\end{array}$ & $\begin{array}{l}\text { All-cause } \\
\text { mortality }\end{array}$ & $\begin{array}{l}\text { Affymetrix } \\
\text { U133A (Santa } \\
\text { Clara, CA, USA) }\end{array}$ & $\begin{array}{l}\text { PGC, FRS3, } \\
\text { C6orf49, } \\
\text { TRFP, BYSL, } \\
\text { CCND3 }\end{array}$ & 129 & 822.6 & 6.0 & 45 \\
\hline $\begin{array}{l}\text { Miller, et al. } \\
\text { [24] }\end{array}$ & $\begin{array}{l}\text { Uppsala, } \\
\text { Sweden }\end{array}$ & $\begin{array}{l}\text { All-cause } \\
\text { mortality }\end{array}$ & $\begin{array}{l}\text { Affymetrix } \\
\text { U133A }\end{array}$ & $\begin{array}{l}\text { PGC, FRS3, } \\
\text { C6orf49, } \\
\text { BYSL, } \\
\text { CCND3 }\end{array}$ & 234 & $1,927.5$ & 10.2 & 54 \\
\hline $\begin{array}{l}\text { Sørlie, et al. } \\
\text { [25] }\end{array}$ & $\begin{array}{l}\text { Stanford } \\
\text { University } \\
\text { (Stanford, } \\
\text { CA, USA) }\end{array}$ & $\begin{array}{l}\text { All-cause } \\
\text { mortality }\end{array}$ & cDNA & $\begin{array}{l}\text { BYSL, } \\
\text { USP49, } \\
\text { CCND3 }\end{array}$ & 76 & 227.6 & 2.5 & 30 \\
\hline $\begin{array}{l}\text { Sotiriou, et al. } \\
\text { [26] }\end{array}$ & $\begin{array}{l}\text { John Radcliffe } \\
\text { (Oxford, UK) }\end{array}$ & $\begin{array}{l}\text { Disease } \\
\text { recurrence }\end{array}$ & $\begin{array}{l}\text { Affymetrix } \\
\text { U133A }\end{array}$ & $\begin{array}{l}\text { PGC, FRS3, } \\
\text { TRFP, BYSL, } \\
\text { CCND3 }\end{array}$ & 94 & 709.9 & 7.3 & $24^{b}$ \\
\hline $\begin{array}{l}\text { van de Vijver, } \\
\text { et al. [27] }\end{array}$ & $\begin{array}{l}\text { The } \\
\text { Netherlands } \\
\text { Cancer } \\
\text { Institute } \\
\text { (Amsterdam) }\end{array}$ & $\begin{array}{l}\text { All-cause } \\
\text { mortality }\end{array}$ & $\begin{array}{l}\text { Agilent } \\
\text { Technologies, } \\
\text { Inc. (Santa } \\
\text { Clara, CA, USA) }\end{array}$ & $\begin{array}{l}\text { PGC, FRS3, } \\
\text { C6orf49, } \\
\text { BYSL, } \\
\text { USP49, } \\
\text { CCND3 }\end{array}$ & 295 & $2,319.8$ & 7.2 & 79 \\
\hline $\begin{array}{l}\text { Wang, et al. } \\
\text { [28] }\end{array}$ & $\begin{array}{l}\text { Erasmus } \\
\text { (Rotterdam, } \\
\text { The } \\
\text { Netherlands) }\end{array}$ & $\begin{array}{l}\text { Disease } \\
\text { recurrence }\end{array}$ & $\begin{array}{l}\text { Affymetrix } \\
\text { U133A }\end{array}$ & $\begin{array}{l}\text { PGC, } \\
\text { C6orf49, } \\
\text { FRS3, } \\
\text { USP49, } \\
\text { BYSL, } \\
\text { CCND3 }\end{array}$ & 285 & $1,843.1$ & 7.2 & $107^{b}$ \\
\hline Total & & & & & 1,241 & $9,048.4$ & 7.4 & 384 \\
\hline
\end{tabular}

aWith endpoint data. bDisease recurrence. 


\section{Competing interests}

The authors declare that they have no competing interests.

\section{Authors' contributions}

EMA carried out statistical analyses and drafted the manuscript. KED carried out genotyping, ER immunohistochemistry, and data cleaning. FL carried out genotyping and selected SNPs for evaluation. MS is responsible for patient recruitment. $D G$ is responsible for collecting patient characteristics and patient follow-up data. DFE is a co-investigator in SEARCH and is involved in study design. AET was responsible for microarray data retrieval and cleaning and advised on data analysis. CC and NEC contributed to study design and interpretation of results. PDPP is a co-investigator in SEARCH, conceived of the study, participated in its design and coordination, and helped to draft the manuscript. All authors read and approved the final manuscript.

\section{Additional files}

The following Additional files are available online:

\section{Additional File 1}

This file contains Supplementary tables 1 and 2, which show the results of the univariate all cause mortality Cox regression analyses for single marker tagSNPs and multimarker tagSNPs.

See http://www.biomedcentral.com/content/ supplementary/bcr2100-S1.doc

\section{Additional File 2}

This file contains Supplementary tables 3 and 4, which show the results of the univariate breast cancer specific mortality Cox regression analyses for single marker tagSNPs and multimarker tagSNPs.

See http://www.biomedcentral.com/content/ supplementary/bcr2100-S2.doc

\section{Additional File 3}

This file contains Supplementary tables 5 and 6, which show additional information regarding the microarray datasets used in the somatic expression analyses. Supplementary table 5 shows additional microarray study and patient characteristics. Supplementary table 6 shows hazard ratios associated with microarray expression of genes in linkage disequilibrium with CCND3 rs2479717.

See http://www.biomedcentral.com/content/ supplementary/bcr2100-S3.doc

\section{Acknowledgements}

This work was supported by a program grant from Cancer Research UK. DFE is a principal research fellow and PDPP is a senior clinical research fellow of Cancer Research UK. NEC is a senior investigator in the National Cancer Institute. EMA is supported by the National Cancer Institute and the $\mathrm{NIH}$-Cambridge Graduate Partnership Program. We thank the women who have taken part in the study, the SEARCH study team, the consultants and general practitioners throughout East Anglia for their help in recruiting patients, and the staff of the Eastern Cancer Registration and Information Centre and the Thames Cancer Registry for providing outcome and clinical data.

\section{References}

1. Office for National Statistics [http://www.statistics.gov.uk]

2. Cancer Research UK [http://www.cancerresearchuk.org]

3. Fitzgibbons PL, Page DL, Weaver D, Thor AD, Allred DC, Clark GM, Ruby SG, O'Malley F, Simpson JF, Connolly JL, Hayes DF, Edge SB, Lichter A, Schnitt SJ: Prognostic factors in breast cancer. College of American Pathologists Consensus Statement 1999. Arch Pathol Lab Med 2000, 124:966-978.

4. Caldon CE, Daly RJ, Sutherland RL, Musgrove EA: Cell cycle control in breast cancer cells. J Cell Biochem 2006, 97:261-274.

5. Sutherland RL, Musgrove EA: Cyclins and breast cancer. J Mammary Gland Biol Neoplasia 2004, 9:95-104.

6. Alkarain A, Slingerland J: Deregulation of p27 by oncogenic signaling and its prognostic significance in breast cancer. Breast Cancer Res 2004, 6:13-21.

7. Bieche I, Olivi M, Nogues C, Vidaud M, Lidereau R: Prognostic value of CCND1 gene status in sporadic breast tumours, as determined by real-time quantitative PCR assays. $\mathrm{Br} J$ Cancer 2002, 86:580-586.

8. Bonin S, Brunetti D, Benedetti E, Gorji N, Stanta G: Expression of cyclin-dependent kinases and CDC25a phosphatase is related with recurrences and survival in women with peri- and post-menopausal breast cancer. Virchows Arch 2006, 448:539-544.

9. Callagy G, Pharoah P, Chin SF, Sangan T, Daigo Y, Jackson L, Caldas $\mathrm{C}$ : Identification and validation of prognostic markers in breast cancer with the complementary use of array-CGH and tissue microarrays. J Pathol 2005, 205:388-396.

10. Huschtscha LI, Noble JR, Neumann AA, Moy EL, Barry P, Melki JR, Clark SJ, Reddel RR: Loss of p16INK4 expression by methylation is associated with lifespan extension of human mammary epithelial cells. Cancer Res 1998, 58:3508-3512.

11. Lopez-Beltran A, MacLennan GT, Montironi R: Cyclin E as molecular marker in the management of breast cancer: a review. Anal Quant Cytol Histol 2006, 28:111-114.

12. McClelland RA, Gee JM, O'Sullivan L, Barnes DM, Robertson JF, Ellis IO, Nicholson RI: p21(WAF1) expression and endocrine response in breast cancer. J Pathol 1999, 188:126-132.

13. Wang L, Shao ZM: Cyclin e expression and prognosis in breast cancer patients: a meta-analysis of published studies. Cancer Invest 2006, 24:581-587.

14. Shu XO, Moore DB, Cai Q, Cheng J, Wen W, Pierce L, Cai H, Gao YT, Zheng W: Association of cyclin D1 genotype with breast cancer risk and survival. Cancer Epidemiol Biomarkers Prev 2005, 14:91-97.

15. Bewick MA, Conlon MS, Lafrenie RM: Polymorphisms in XRCC1, XRCC3, and CCND1 and survival after treatment for metastatic breast cancer. J Clin Oncol 2006, 24:5645-5651.

16. Schondorf T, Eisele L, Gohring UJ, Valter MM, Warm M, Mallmann P, Becker M, Fechteler R, Weisshaar MP, Hoopmann M: The V109G polymorphism of the p27 gene CDKN1B indicates a worse outcome in node-negative breast cancer patients. Tumour Biol 2004, 25:306-312.

17. Skol AD, Scott $L$, Abecasis GR, Boehnke M: Joint analysis is more efficient than replication-based analysis for two-stage genome-wide association studies. Nat Genet 2006, 38:209-213.

18. Sobin LH, Wittekind C: TNM Classification of Malignant Tumours 5th edition. New York: Wiley-Liss; 1997.

19. de Bakker PI, Yelensky R, Pe'er I, Gabriel SB, Daly MJ, Altshuler D: Efficiency and power in genetic association studies. Nat Genet 2005, 37:1217-1223.

20. International HapMap Project [http://www.hapmap.org] 
21. NIEHS [National Institute of Environmental Health Sciences] Environmental Genome Project [http://www.niehs.nih.gov/ envgenom/home.htm]

22. Blenkiron C, Goldstein LD, Thorne NP, Spiteri I, Chin SF, Dunning MJ, Barbosa-Morais NL, Teschendorff AE, Green AR, Ellis IO, Tavaré S, Caldas C, Miska EA: MicroRNA expression profiling of human breast cancer identifies new markers of tumour subtype. Genome Biol 2007, 8:R214.

23. Chin K, DeVries S, Fridlyand J, Spellman PT, Roydasgupta R, Kuo WL, Lapuk A, Neve RM, Oian Z, Ryder T, Chen F, Feiler H, Tokuyasu T, Kingsley C, Dairkee S, Meng Z, Chew K, Pinkel D, Jain A, Ljung BM, Esserman L, Albertson DG, Waldman FM, Gray JW: Genomic and transcriptional aberrations linked to breast cancer pathophysiologies. Cancer Cell 2006, 10:529-541.

24. Miller LD, Smeds J, George J, Vega VB, Vergara L, Ploner A, Pawitan Y, Hall P, Klaar S, Liu ET, Bergh J: An expression signature for p53 status in human breast cancer predicts mutation status, transcriptional effects, and patient survival. Proc Natl Acad Sci USA 2005, 102:13550-13555.

25. Sørlie T, Perou CM, Tibshirani R, Aas T, Geisler S, Johnsen H, Hastie T, Eisen MB, Rijn M van de, Jeffrey SS, Thorsen T, Quist $H$, Matese JC, Brown PO, Botstein D, Eystein Lønning P, BørresenDale AL: Gene expression patterns of breast carcinomas distinguish tumor subclasses with clinical implications. Proc Natl Acad Sci USA 2001, 98:10869-10874.

26. Sotiriou C, Wirapati $P$, Loi S, Harris A, Fox S, Smeds J, Nordgren $H$, Farmer P, Praz V, Haibe-Kains B, Desmedt C, Larsimont D, Cardoso F, Peterse H, Nuyten D, Buyse M, Vijver MJ Van de, Bergh J, Piccart M, Delorenzi M: Gene expression profiling in breast cancer: understanding the molecular basis of histologic grade to improve prognosis. J Natl Cancer Inst 2006, 98:262-272.

27. Vijver MJ van de, He YD, van't Veer $\amalg$, Dai H, Hart AA, Voskuil DW, Schreiber GJ, Peterse JL, Roberts C, Marton MJ, Parrish M, Atsma D, Witteveen A, Glas A, Delahaye L, Velde T van der, Bartelink H, Rodenhuis S, Rutgers ET, Friend SH, Bernards R: A geneexpression signature as a predictor of survival in breast cancer. N Engl J Med 2002, 347:1999-2009.

28. Wang $Y$, Klijn JG, Zhang Y, Sieuwerts AM, Look MP, Yang F, Talantov D, Timmermans M, Meijer-van Gelder ME, Yu J, Jatkoe T, Berns EM, Atkins D, Foekens JA: Gene-expression profiles to predict distant metastasis of lymph-node-negative primary breast cancer. Lancet 2005, 365:671-679.

29. Teschendorff AE Naderi A, Barbosa-Morais NL, Pinder SE, Ellis IO, Aparicio S, Brenton JD, Caldas C: A consensus prognostic gene expression classifier for ER positive breast cancer. Genome Biol 2006, 7:R101.

30. Sanchez LM, Freije JP, Merino AM, Vizoso F, Foltmann B, LopezOtin C: Isolation and characterization of a pepsin $C$ zymogen produced by human breast tissues. J Biol Chem 1992, 267:24725-24731.

31. Diez-Itza I, Merino AM, Tolivia J, Vizoso F, Sanchez LM, Lopez-Otin $\mathrm{C}$ : Expression of pepsinogen $\mathrm{C}$ in human breast tumours and correlation with clinicopathologic parameters. $\mathrm{Br} J$ Cancer 1993, 68:637-640.

32. Vizoso F, Sanchez LM, Diez-Itza I, Merino AM, Lopez-Otin C: Pepsinogen $C$ is a new prognostic marker in primary breast cancer. J Clin Oncol 1995, 13:54-61.

33. Scorilas A, Diamandis EP, Levesque MA, Papanastasiou-Diamandi A, Khosravi MJ, Giai M, Ponzone R, Roagna R, Sismondi P, LopezOtin C: Immunoenzymatically determined pepsinogen $C$ concentration in breast tumor cytosols: an independent favorable prognostic factor in node-positive patients. Clin Cancer Res 1999, 5:1778-1785

34. Kimber SJ: Molecular interactions at the maternal-embryonic interface during the early phase of implantation. Semin Reprod Med 2000, 18:237-253.

35. Ayala GE, Dai H, Li R, Ittmann M, Thompson TC, Rowley D, Wheeler TM: Bystin in perineural invasion of prostate cancer. Prostate 2006, 66:266-272.

36. Chassin D, Bénifla JL, Delattre C, Fernandez H, Ginisty D, Janneau $\mathrm{JL}$, Prade M, Contesso G, Caillou B, Tournaire M, Frydman R, Dominique E, Bedossa P, Bidart JM, Bellet D, Koman A: Identification of genes overexpressed in tumors through preferential expression screening in trophoblasts. Cancer Res 1994, 54:5217-5223.

37. Teufel A, Weinmann A, Galle PR, Lohse AW: Characterization of OEBT, a LIM protein. Int J Mol Med 2005, 15:513-518.
38. Huang L, Watanabe M, Chikamori M, Kido $\mathrm{Y}$, Yamamoto T, Shibuya M, Gotoh N, Tsuchida N: Unique role of SNT-2/ FRS2beta/FRS3 docking/adaptor protein for negative regulation in EGF receptor tyrosine kinase signaling pathways. Oncogene 2006, 25:6457-6466.

39. Chikamori M, Fujimoto J, Tokai-Nishizumi N, Yamamoto T: Identification of multiple SNT-binding sites on NPM-ALK oncoprotein and their involvement in cell transformation. Oncogene 26:2950-2954.

40. Quesada V, Diaz-Perales A, Gutierrez-Fernandez A, Garabaya C, Cal S, Lopez-Otin C: Cloning and enzymatic analysis of 22 novel human ubiquitin-specific proteases. Biochem Biophys Res Commun 2004, 314:54-62.

41. Xiao H, Tao Y, Roeder RG: The human homologue of Drosophila TRF-proximal protein is associated with an RNA polymerase II-SRB complex. J Biol Chem 1999, 274:3937-3940. 